\title{
Prostorové rozhraní informačního systému malé obce řešené v Open Source Software
}

\author{
Karel Jedlička \\ Department of Mathematics, Geomatics section, \\ Faculty of Applied sciences, University of West Bohemia, \\ E-mail: smrcek@kma.zcu.cz \\ Autor je podporován Výzkumným záměrem MŠM 497775130. \\ Jakub Orálek \\ Department of Mathematics, Geomatics section, \\ Faculty of Applied sciences, University of West Bohemia, \\ E-mail: fugas9@seznam.cz
}

\section{Klíčová slova:}

Informační systém malé obce, geografické databáze, geografický informační systém, open source, PostgreSQL, PostGIS, UMN MapServer, JUMP, QGIS, Výmenný formát katastru nemovitostí (VF ISKN).

\begin{abstract}
Abstrakt
Př́spěvek si klade za cíl představit možnosti open source software pro implementaci prostorového rozhraní informačního systému malé obce.

Zabývá se návrhem projektu po jednotlivých částech: identifikace požadavků zastupitelského úradu (uživatele systému), popis obecné architektury systému a volba vhodných (nekomerčních) technologii pro jeho implementaci. Součástí projektu je i popis vyvinuté technologie pro import nejdůležitějších datových vrstev (informací o vlastnictví) do systému.

Článek je doplněn výčtem využitelných datových zdrojů pro informační systém malé obce v České republice.
\end{abstract}

\section{Úvod}

Cílem projektu je návrh finančně nenáročného řešení informačního systému pro správu a evidenci městského majetku a souvisejících agend, který má sloužit jak pro zjednodušení administrativní práce zastupitelského úřadu, tak i pro podporu jeho rozhodování. Projekt má tři fáze:

- První fází je identifikace obecných požadavků zastupitelstva menší obce na informační systém, která byla provedena v rámci práce Novotného 2005).

- Druhá fáze spočívá ve volbě vhodných technologií, návrhu jejich využití a implementace obecného prostorového i atributového rozhraní. Důraz je přitom kladen na robustnost, bezpečnost, nízkou nákladovost a v neposlední řadě na uživatelskou jednoduchost zvoleného řešení. 
- Navazující třetí fáze plní vytvořený systém existujícími prostorovými i atributovými datovými zdroji. Její podstatou je návrh a implementace plynulého přechodu (či propojení) od stávajících způsobů správy a evidence obecního majetku (a souvisejících agend) k digitálnímu řešení. Lze ji rozdělit na dvě části. První se zabývá datovými zdroji standardizovanými na státní úrovni (externí zdroje), druhá interními datovými zdroji obce.

\section{Obecná architektura systému}

\section{Uživatelské požadavky}

Informační systém obce využívají hlavně pracovníci obecního úřadu a občané. Informační systém by měl usnadnit řízení obce (správa věcí veřejných, služba veřejnosti), propagace obce, ekonomické řízení. Správa věcí veřejných zahrnuje:

- správu a údržbu komunikací,

- územní rozvoj a plánování,

- čistotu v obci,

- správu majetku,

- bezpečnost,

- údržbu sportovních a kulturních zařízení,

- zavádění infrastruktury a inženýrských sítí.

Př́kladem služby veřejnosti potom může být:

- podávání informací,

- zajištování dopravní obslužnosti,

- zajištování komunikace mezi státem a občanem,

- napomáhání řešení problémů občana.

Zpracováno podle Novotného (2005).

\section{Struktura}

Informační systém malé obce (dále ISMO) je systém, v rámci kterého lze definovat čtyři hlavní skupiny uživatelů, lze říci uživatelské role:

- Administrátor systému - role rozdělená mezi dodavatele technologií a pracovníka zastupitelského úřadu. Dodavatel technologií instaluje a zprovozní systém, dále proškolí místního administrátora v běžných provozních úkonech. Dodavatel technologií poté zařizuje pouze méně běžné úpravy systému. Přesné rozdělení této role mezi zastupitelský úřad a dodavatele, závisí na místních podmínkách. 
- Správce a editor dat - úředník nebo skupina úředníků místního úřadu. Role spočívá v udržování dat systému v aktuálním a konzistentním stavu. Prováděno je to kontinuální aktualizací interních dat obce (např. registr obyvatel, pozemků a budov, územní plán, technická mapa) a pravidelnou dávkovou aktualizací dat z externích zdrojů (dnes je typickým př́kladem katastrální mapa).

- Dodavatel externích dat - externí organizace dodávající datové zdroje, např. katastrální mapu, ortofotomapu, základní mapa, atp., více v kapitole Datové zdroje.

- Ostatni uživatelé - většinou obyvatelé obce, ale i další zájemci, např. úřady vyšších územně správních celků. Jedná se většinou o pasivní roli př́jemců informace, ovšem i tito uživatelé mají možnost ovlivňovat systém. Většinou však pouze zprostředkovaně, přes upozornění na př́padné nesrovnalosti odeslané správci dat, který je povinen na připomínku reagovat.

Pro návrh systému mající výše uvedené role, lze s úspěchem použít distribuované prostředí počítačových sítí a klient server řešení, resp. jeho třívrstvou variantu (Prezentační vrstva - uživatelské rozhraní; aplikační vrstva - funkcionalita, dávající SW jeho charakter; vrstva služeb - nejčastěji databázová vrstva), která je znázorněna na obrázku 1. Další informace o vícevrstvých architekturách lze nalézt např. v prácei FASTIE (1999) a SEI (2005).

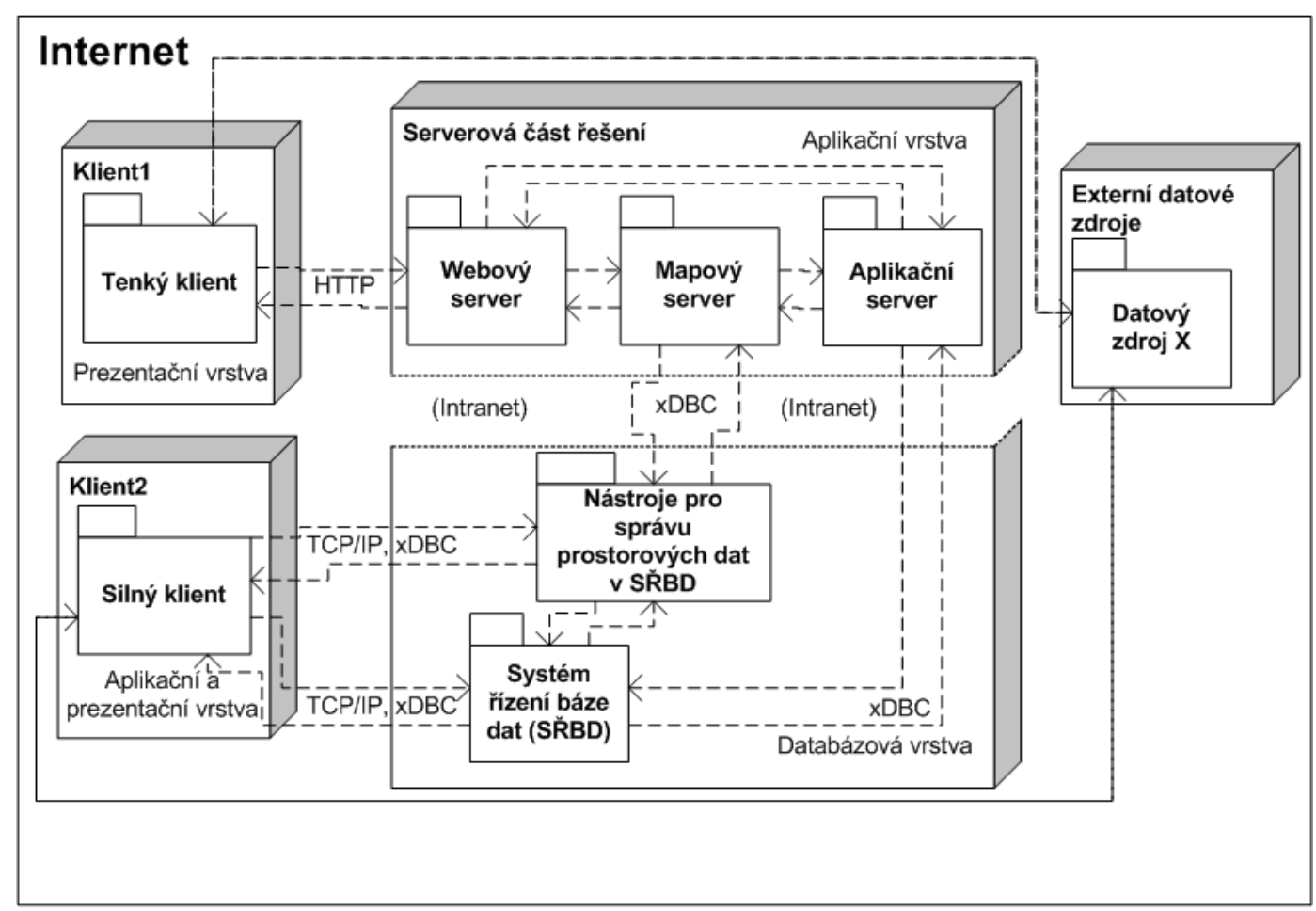

Obr. 1.: Obecné schéma technologického řešení ISMO - zakresleno v unified modeling language (UML). Více o UML lze nalézt PAGE-JONES (2001)

Základní komponentou distribuovaného systému je relační databáze. Protože ISMO je informačním systémem o území, databáze musí umožňovat ukládat nejen atributová, ale i pro- 
storová data (dohromady nazývaná geografická data). Aby nedocházelo k porušení integrity mezi atributovými a prostorovými daty, je celá geografická databáze př́istupná přes jednotné rozhraní, které je definováno systémem řízení báze dat (SŘBD) a nástroji pro správu prostorových dat. Zmiňované rozhraní je postaveno na některé z technologií přípojení k databázi, at již proprietální nebo standardizované a je v obr. 1 označeno zkratkou xDBC.

Silný klient je software, který v obsahuje aplikační logiku provázanou s uživatelským rozhraním - převzato z FASTIE (1999). Klient se připojuje přímo k databázové vrstvě přes definované rozhraní. Komunikace probíhá v Intranetu či v Internetu, proto je volen standardní sítový protokol TCP/IP.

Tenký klient (typicky webový prohlížeč) obsahuje pouze prezentační vrstvu, která přes definované rozhraní, pro sítové prostředí většinou HTTP(s) protokol, komunikuje s aplikací, či aplikační vrstvou.

Aplikační vrstva je sada mezi sebou komunikujících aplikací - aplikačních serverů. Ty mezi sebou komunikují protokoly, které jsou závislé na typech jednotlivých serverů. Vrstva se obvykle skládá z webového serveru, který navenek komunikuje s tenkým klientem a předává jeho požadavek dalším serverům ve vrstvě (např. mapovému serveru pro požadavek na geografická data). Aplikační server požadavek zpracuje, v př́ípadě potřeby komunikuje s databázovou vrstvou, a výsledek předává webovému serveru. Ten odesílá data zpět klientovi. Každá z aplikací přitom komunikuje přes stanovená rozhraní (protokoly).

ISMO je nutno definovat jako otevřený systém, který umožňuje i práci s externími zdroji (více viz kapitola Datové zdroje).

\section{Přehled využitelných technologií}

Pro implementaci systému lze obecně využít open source technologií, komerčních technologií nebo jejich kombinace. Vzhledem k požadavku na nízkonákladové řešení, jsou voleny technologie open source. Jejich přehled následuje.

\section{Databáze a prostorová rozšíření}

Co se týče klasických databází na bázi open source, existuje několik kvalitních produktů. Z těch známějších lze uvést MySQL [8], PostgreSQL [7], MaxDB, Firebird a Ingres. Lze říci, že v současné době je nejrozšířenějšś atributová databáze MySQL. V informačním systému obce je ovšem kladen důraz na podporu prostorových dat a tam je nejsilnější databáze PostgreSQL, resp. její rozšíření PostGIS. MaxDB, Firebird ani Ingres prostorová data nepodporují. MySQL ve své poslední verzi nabízí velmi dobré prostorové rozšsiření, v mnoha ohledech srovnatelné s PostGIS. Využívá stejných objektových modelů jako PostGIS. Hlavní výhodou PostgreSQL/PostGIS oproti MySQL je větší podpora open source silných klientů, možnost ukládat $3 \mathrm{D}$ i $4 \mathrm{D}$ data a větší počet vestavěných funkcí pracujících s prostorovými daty.

\section{Mapové servery}

Existuje několik open source mapových serverů: Map server, Geoserver, ALOV Map, MapIt!, Mapzoom, JShape. Mapové servery MapIt! a JShape nejsou př́liš vhodné, jelikož podporují velmi málo formátů (JShape pracuje pouze s shapefile a MapIt! jen s rastrovými daty). Mapzoom je velmi jednoduchý nástroj a slouží pouze pro tvorbu statických map. Jako zajímavý 
mapový server se jeví ALOV Map, který umí pracovat s vektorovými i rastrovými daty v souborové i databázové (MySQL) formě, podporuje WMS. Veškeré tyto možnosti poskytuje také UMN Map server. Ten navíc disponuje větší podporou komunikačních protokolů (např. WFS), databázových systémů (např. PostgreSQL), výstupů (např. PDF) a v neposlední řadě obsahuje přehlednější a obsáhlejší dokumentaci.

\section{Webové servery}

Existuje velké množství open source webových serverů. Jigsaw a Tomcat jsou napsány kompletně v jazyku Java. Jejich hlavní prioritou je zavedení webových technologií využívajících tento jazyk (mluví se o tzv. Javových serverech). Hlavní výhodou programu Jetty (napsaný také v jazyku Java) je kombinace klasického HTTP serveru s javovým serverem. Nejrozšírenějším webovým serverem na bázi open source je Apache (napsaný v jazyku C). Podporuje velké množství technologií (např. PHP, CGI), SSL, lze ho propojit s databází PostgreSQL. Výhodou je také velké množství dokumentace a webových fór.

\section{Software pro vizualizaci geodat}

GRASS (Geographic Resources Analysis Support System) je profesionální GIS jehož hlavní síla je v prostorových, zejména rastrových analýzách. GRASS podporuje standardy WMS a WFS, možné je také propojení s PostGIS. Pro menší obce je ovšem tento software zbytečně komplexní a složitý na ovládání.

uDIG (User-friendly Desktop Internet GIS) lze použít jednak jako geoprostorovou aplikaci i pro vytváření nových odvozených aplikací. Podporuje standardy WMS a WFS a propojení s PostGIS databází. Nevýhodou je nedostatek rozšiřujících modulů dostupných na internetu a podpora malého množství datových formátů.

JUMP (Java Unified Mapping Platform) je celý napsán v jazyku Java a mezi jeho hlavní výhody patř́i možnost rozšsiřrení o nové moduly, možnost provozu nezávisle na operačním systému. Přídavné moduly nabízejí např́íklad právě propojení s databází PostGIS, podporu WFS (Standard WMS je podporován př́mo), Podporu IMS. Na internetu je možné získat mnoho dalších rozšiřujících modulů.

Quantum GIS (QGIS) umožňuje propojení s PostGIS a pomocí přídavného modulu je zajištěna podpora WMS. Díky rozšiřujícím modulům lze do Quantum GIS přidávat nové funkce a nástroje.

Požadavek na jednoduchou práci v systému a na jeho bezpečnost vede k volbě technologií, pro které existuje silný vývojový tým, jsou prověřené úspěšným nasazením a existují pro ně rozsáhlé dokumentační materiály a návody na použití.

Příkladem takového open source řešení je i autory článku zvolená kombinace technologií databáze PosgreSQL s prostorovým rozšířením PostGIS, mapovým serverem UMN MapServer, webovým serverem Apache, tenkým klientem v podobě webového prohlížeče (s podporou JavaScriptu) a silnýmmi klienty JUMP a QGIS, které popisuje následující kapitola. 


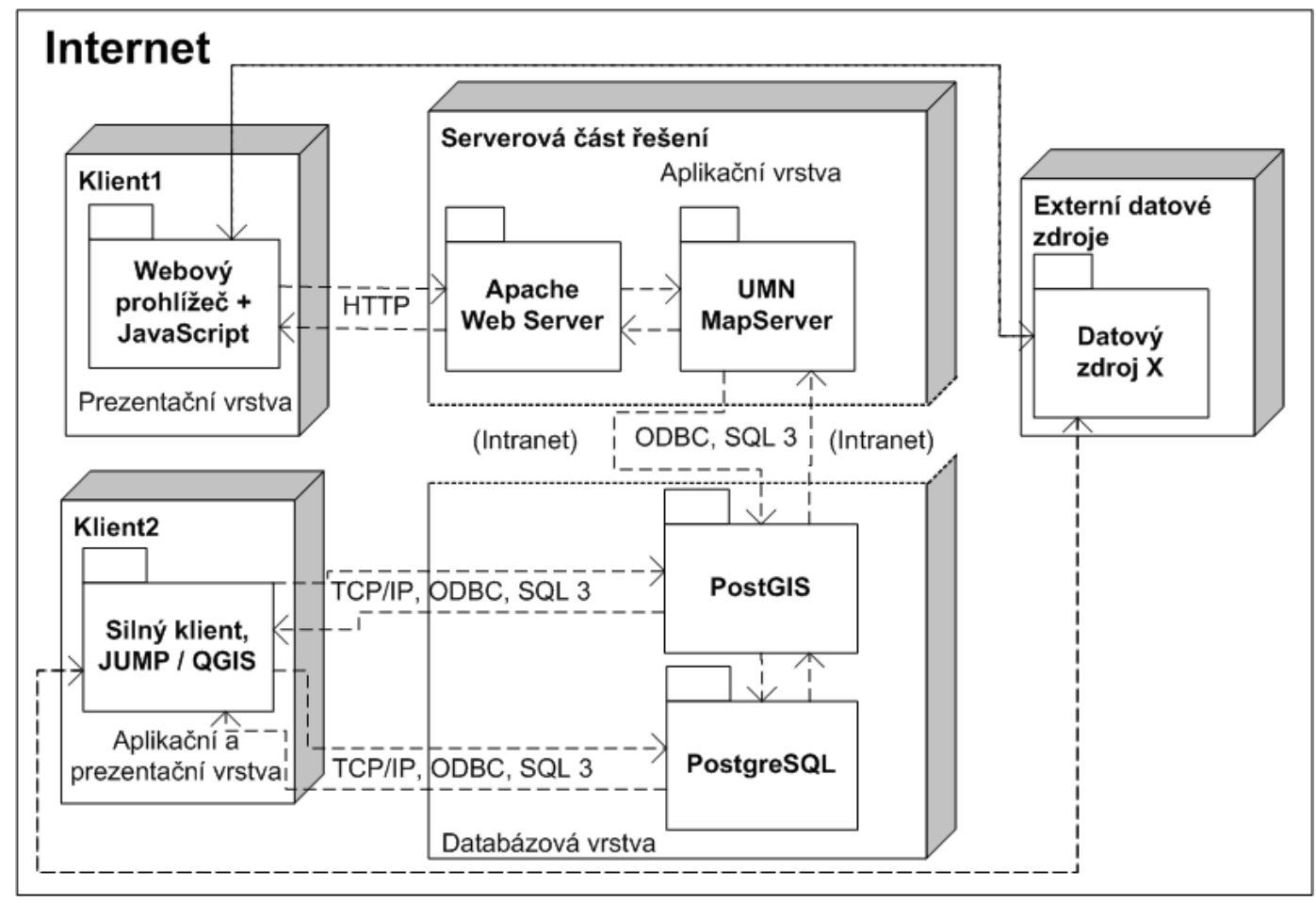

Obr. 2.: Schéma zvoleného open source technologického řešení Informačního systému malé obce.

\section{Zvolené open source řešení}

Zvolené open source řešení ISMO je složeno z technologií zobrazených na obrázku 2 a popsaných níže. Jako relační databáze s možností ukládání prostorových dat zde slouží PostgreSQL s prostorovým rozššřením PostGIS. Databáze komunikuje přes rozhraní ODBC a jazyk SQL3 bud' přímo se silnými klienty (JUMP/QGIS) nebo s aplikační vrstvou, která je tvořena mapovým serverem UMN MapServer a webovým serverem Apache, který následně přes $\operatorname{HTTP}(\mathrm{s})$ protokol komunikuje s tenkým klientem (webovým prohlížečem).

\section{PostgreSQL}

PostgreSQL (http://www.postgresql.org ${ }^{1}$ ) je open source relační databázový systém pro práci s klasickými atributovými daty. Může být provozován na operačních systémech Linux, UNIX, Windows a Mac OS X. Plně podporuje cizí klíče, spojování tabulek, pohledy, triggery a uložené procedury. Zahrnuje v sobě většinu datových typů z SQL92 a SQL99. Podporuje ukládání velkých binárních objektů, jako jsou obrázky, zvuky nebo video. Př́́kazy v PostgreSQL jsou zadávány pomocí prŕkazového řádku. Jako pomocnou aplikaci lze použít pgAdmin III, který k databázi poskytuje grafické uživatelské prostředí. PgAdmin III podporuje stejné operační systémy jako PostgreSQL. S aplikační vrstvou (mapovým serverem, či silným klientem -

\footnotetext{
${ }^{1}$ http://www.postgresql.org
} 
JUMP, QGIS) komunikuje pomocí sítového protokolu TCP/IP přes rozhraní ODBC jazykem SQL 3. Podrobnosti lze nalézt v dokumentaci PostgreSQL (2005).

\section{PostGIS}

PostGIS (http://www.postgis.org ${ }^{2}$ ) přidává podporu geografickým objektovým datovým typům do PostgreSQL. Vychází z OGC 99-049 (1999). Konkrétně využívá objektové datové typy: point, linestring, polygon, multi point, multilinestring, multipolygon, geometrycollection. Dále obsahuje několik set prostorových funkcí. Každý objekt použitý v PostGIS lze vytvořit formou WKT (well-known-text) nebo WKB (well-known-binary). V databázi jsou potom prostorové informace uloženy v binárním tvaru. Podrobnější informace o práci v PostGIS poskytuje Refraction Research (2006).

\section{UMN MapServer}

UMN MapServer (http://mapserver.gis.umn.edu ${ }^{3}$ ) je program vhodný pro tvorbu internetových mapových aplikací. Lze jej používat na operačních systémech Linux, Windows a Mac OS X. MapServer může na základě parametrů obdržených od webového serveru vytvořit obraz mapy nebo pomocí šablony vytvořit HTML dokument s obrazem mapy. Spojením MapServeru s DHTML, PHP, JavaScriptem nebo jinými programovacími jazyky mohou vzniknout velmi zajímavé interaktivní mapy s mnoha funkcemi.

\section{Apache WebServer}

Apache je webový (HTTP) server (http://www.apache.org ${ }^{4}$ ), který lze spustit na operačních systémech Linux, Windows, Unix a Mac OS X. Jak plyne již z jeho názvu, komunikuje s klientem přes HTTP protokol.

\section{JUMP}

JUMP - Java Unified Mapping Platform (http://jump-project.org $/{ }^{5}$ ) je aplikace založená na grafickém uživatelském rozhraní, slouží k zobrazení a úpravě geografických dat. Zahrnuje mnoho funkcí pro základní práci s geodaty. Je navržen tak, aby ho bylo možné snadno rozšírit a vyvíjet. Celý program je napsán v jazyku Java, což má několik výhod: JUMP spustí uživatelé jakéhokoli operačního systému, nabízí přístup ke všem svým funkcím a je snadno rozšiřitelný. Více se lze dočíst v publikaci Vivid Solutions (2003).Mezi základní rysy JUMP patří:

- podpora formátů GML, ESRI Shapefile, WKT,

- podpora PostGIS zajištěna přidaným modulem,

- možnost zobrazovat atributy a geometrické souřadnice vybraným prvkům,

\footnotetext{
${ }^{2}$ http://www.postgis.org

${ }^{3}$ http://mapserver.gis.umn.edu

${ }^{4}$ http://www.apache.org

${ }^{5}$ http://jump-project.org/
} 
- změna symbologie,

- popisy geografických prvků,

- editace geometrie i atributů,

- WMS klient,

- možnost provádět některé analýzy,

- snadná rozšiřitelnost.

\section{Quantum GIS (QGIS)}

QGIS (http://qgis.org ${ }^{6}$ ) je aplikace, která slouží pro zobrazení geografických dat. Obsahuje mnoho běžných prostorových funkcí. Nové funkce a nástroje lze vkládat pomocí přídavných modulů. Lze ji spustit na operačních systémech Linux, Unix, Mac OS X, Windows. QGIS podrobně popisuje Sherman (2005). Základní rysy Quantum GIS jsou:

- podpora všech vektorových formátů obsažených v knihovně OGR,

- podpora všech rastrových formátů obsažených v knihovně GDAL,

- propojení s PostGIS databází,

- propojení s GRASS a možnost provádět prostorové analýzy,

- lze zobrazovat atributové tabulky vybraným geografickým prvkům,

- změna symbologie,

- popisy geografických prvků,

- export do map souboru používaného MapServerem,

- možnosti rozšśřrení o přídavné moduly.

\section{Webový prohlížeč a skripty na straně klienta}

Existuje několik webových prohlížečů (napr. Internet Explorer, Mozilla Firefox, Opera, Netscape, Safari). V̌̌echny komunikují se serverem přes HTTP protokol a jejich základem je schopnost zobrazovat HTML dokumenty. S rozšiřováním internetu se rozšírilily i technologie podporované prohlížeči. Např. možnost vytvářet formuláře, vkládat zvukové a video soubory, flash animace. Statické HTML lze rozšíriit o některé skriptovací jazyky běžící na straně klienta (webový prohlížeč). Nejpoužívanější jsou Java Script a VB Script. Tyto skriptovací jazyky umožňují na základě události (najetí kurzoru myši na objekt, kliknutí, načtení stránky, atd.) dynamicky měnit HTML dokument.

\footnotetext{
${ }^{6}$ http://qgis.org
} 


\section{Datové zdroje}

Datové zdroje pro ISMO lze rozdělit do dvou skupin: externí a interní. Externí zdroje jsou většinou standardizovány na státní (někdy krajské) úrovni a obci slouží hlavně jako podkladová data. Do ISMO jsou bud'to importovány nebo zapojeny přes standardizované webové služby, v př́padě geografických dat přes Web Map Service (WMS) nebo Web Feature Service (WFS) definované v OGC 05-008 (2005).

WMS definuje mapu jako zobrazení geografické informace jako digitální obrazový soubor. Mapa a samotná data jsou něco jiného. Mapy vytvořené podle specifikace WMS jsou prezentována v rastrových nebo vektorových formátech (např. SVG, CGM). Oproti tomu WFS poskytuje přímo zdrojová geodata ve formátu GML.

\section{Externí}

Fundamentálním externím zdrojem pro ISMO jsou informace o vlastnictví a užívání nemovitého majetku v katastru obce. Tato data poskytuje Český úřad zeměměřický a katastrální (dále ČÚZK) v několika formách $\mathrm{v}$ závislosti na způsobu vedení katastrálního operátu v konkrétním území:

- Digitální katastrální mapa (DKM) včetně souboru popisných informacích (SPI) ve výměnném formátu Informačního systému katastru nemovitostí (VF ISKN) (více viz. ČÚZK b). Popis importu těchto dat do ISMO následuje v podkapitole Import VF ISKN.

- Hybridní katastrální mapa; geometrie parcel je předávána v rastrovém formátu *.cit (více viz. ČÚZK a), definiční body parcel předávané ve vektorovém formátu, SPI ve VF ISKN.

- Analogová katastrální mapa; data je nutno nascannovat a ve vektorové formě vytvořit minimálně definiční body parcel, SPI ve VF ISKN (digitalizace SPI dokončena v roce 1998).

Popis importu druhých dvou verzí katastrálních dat je popsán v podkapitole Import analogové či hybridní katastrální mapy.

Katastrální data jsou podle vyhlášky O poskytování údajů z katastru nemovitostí České republiky, č.162/2001 poskytována samosprávám zdarma.

Mezi další významné externí zdroje dat patří servery, poskytující prostorová data:

\section{CENIA}

Česká informační agentura životního prostředí (CENIA) vytvořila mapový server http://geoportal.cenia.cz ${ }^{7}$ který se stal důležitou součástí portálu veřejné správy. Mapový server nabízí mapy formou samostatné internetové aplikace i pomocí mapových služeb WMS a ArcIMS. Poskytovaná data se vztahují k celé České republice a jsou pravidelně aktualizována. Konkrétně zde lze nalézt několik tématických map z oblasti geologie, životního prostředí nebo územně správní členění, topografické mapy ČR, ortofotomapu, mapy týkající

${ }^{7}$ http://geoportal.cenia.cz 
se obyvatel. Např. ortofotomapu nebo geologickou mapu mohou využít všechny obce ČR, naproti tomu např. mapu chráněných území využijí obce, do kterých chráněná území zasahují. Ne př́liš potřebné pro obce jsou naopak některé tématické mapy mající nejmenší jednotku jedno katastrální území (např. hustota obyvatel).

\section{IZGARD}

Internetový zobrazovač geografických armádních dat http://arwen.ceu.cz/website/startovani ${ }^{8}$ je projekt zpřístupňující data vojenského geografického informačního systému (VGIS). Byl vytvořen Vojenským geografickým a hydrometeorologickým úřadem se sídlem v Dobrušce. Poskytuje digitální atlas ČR, letecké měřické snímky a letecké snímky z povodní. Digitální atlas mohou využít všechny obce, naproti tomu snímky z povodní jsou užitečné především obce postižené záplavami. Všechna data jsou dostupná pouze pomocí mapové služby ArcIMS a ta není většinou v open source programech podporována. Výjimku tvoří program JUMP, pro který podpora ArcIMS již existuje formou rozšiřujícího modulu.

\section{ÚHÚL}

Ústav pro hospodářskou úpravu lesů http://www.uhul.cz ${ }^{9}$ je řízen ministerstvem zemědělství. Tento úřad provádí velké množství činností vztahující se k lesům celé ČR. Jedná se především o inventarizaci lesů, oblastní plány rozvoje lesů, informační a datové centrum a typologii lesů. Mimo to poskytuje několik mapových projektů formou WMS a WFS. Často se jedná o ne př́liš podrobná data (např. mapa eroze půdy) nebo o data vztahující se jen $\mathrm{k}$ malé části republiky (např. úprava chemismu půd), takže z celkového pohledu je obce př́iliš nevyužijí. Nacházejí se zde ale i data vhodná pro velké množství obcí (např. oblastní plány rozvoje lesů).

\section{Interní}

Interní datové zdroje jsou data, jejichž správu a aktualizaci má na starosti obec. Jejich struktura byla analyzována v práci Novotného 2005, zde je uveden jejich stručný výčet:

- majetková a finanční agenda,

- rozpočet,

- poplatky od občanů,

- registr obyvatel, pozemků a budov,

- technická mapa,

- územní plán.

Struktura interních datových zdrojů má převážně atributový charakter (výjimku tvoří technická mapa města a územní plán) a může se velmi lišit (především je to otázka investovaných peněz) obec od obce. Návrh importu a propojení interních dat obce je tak silně závislý na konkrétním území a přesahuje rámec tohoto textu.

\footnotetext{
${ }^{8}$ http://arwen.ceu.cz/website/startovani

${ }^{9}$ http://www. uhul.cz
} 


\section{Import VF ISKN}

Importem dat výměnného formátu ISKN do datových bází, které jsou podporovány open source software, databází se zabýval např. Landa (2005), který ukládal atributová data do databáze PostgreSQL a vektorová data do nativního formátu GIS GRASS. Součástí návrhu ISMO je implementace prostorových i atributových dat VF ISKN do PostGIS.

Výměnný formát informačního systému katastru nemovitostí je také nazýván novým výměnným formátem (NVF). Jeho import do databáze PostgreSQL/PostGIS je zajištěn aplikací vytvořenou v rámci projektu $\mathrm{v}$ jazyce Python. $\mathrm{K}$ tomu bylo zapotřebí propojit Python $\mathrm{s}$ databází přes standardní rozhraní ODBC. Před spuštěním programu je potřeba mít vytvořenou PostGIS databázi.

Uživatel při importu zadává pouze název propojení ODBC, uživatelské jméno, heslo, název souboru ve formátu NVF (je umístěn v kořenovém adresáři aplikace) a cílovou databázi v PostGIS. Z programátorského hlediska lze program rozdělit do několika kroků:

- Pokud není existující databáze prázdná vymažou se všechny její tabulky (kromě dvou standardních PostGIS tabulek(spatial_ref_sys, geometry_columns).

- Vytvoření tabulek podle struktury ISKN a jejich naplnění atributovými daty.

- Vytvoření dvou souborů obsahují SQL př́kazy pro tvorbu primárních resp. cizích klíčủ.

- Vytvoření primárních a poté cizích klíčů v databázi.

- Vytvoření geometrie podle OGC specifikací ve vybraných tabulkách (viz. obr. 3 - datový model).

Výsledný datový model (jehož nejdůležitější části ukazuje obr. 3) obsahuje několik desítek tabulek, z nichž tři obsahují kromě atributových dat i geometrii. Hranice parcel (HP) a další prvky mapy (DPM) mají geometrii typu LINESTRING, parcely (PAR) jsou typu POLYGON. Geometrii k dalším tabulkám lze jednoduše doprogramovat analogicky jako v těchto třech případech. Např. k tabulce budov (BUD) by bylo možné přidat geometrii polygonu.

Geometrie u jednotlivých tabulek vycházejí ze souřadnic uložených v tabulce bodů polohopisu (SOBR). Souřadnice bodů se však nacházejí i v jiných tabulkách (např. DPM, SBM, $\mathrm{OP})$, které je možno využít při přidávání další geometrie. Pro obce je důležité vizualizovat především vlastnické vztahy (které souvisí s tabulkou parcel), proto nejsou do databáze další prostorové sloupce přidány.

Kvůli snadnější vizualizaci pomocí silných klientů je dobré předpřipravit data v databázi. Jako ukázka $\mathrm{v}$ tomto datovém modelu poslouží přidané sloupce název druhu pozemku a název způsobu využití pozemku z tabulky druhu pozemku (drupoz), resp. způsobu využití pozemku (zpvypo) do tabulky parcel (PAR). V podstatě se jedná o "překopírování" těchto sloupců na základě vazby mezi tabulkami.

\section{Import analogové či hybridní katastrální mapy}

Při importu analogové mapy do ISMO je potřeba uskutečnit tři hlavní kroky: 


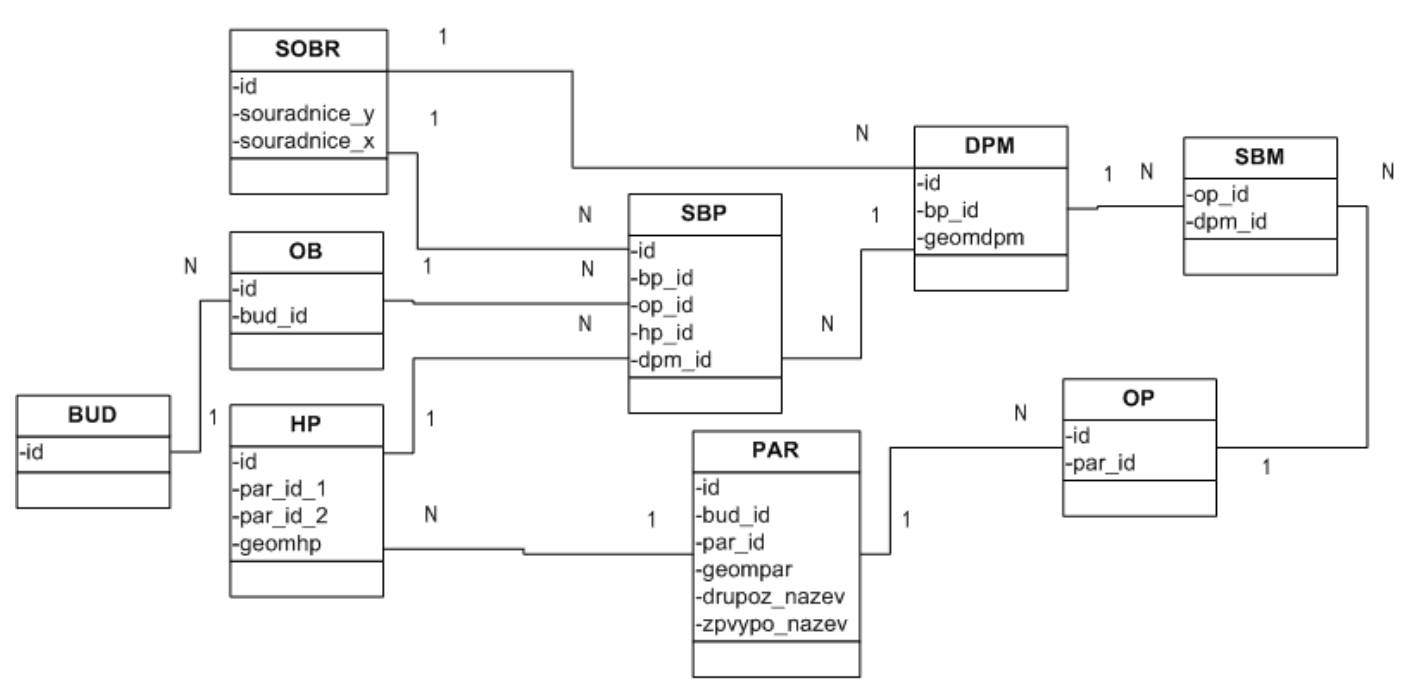

Obr. 3.: Stěžejní část výsledného datového modelu po importu VF.

- scannování rastrů PK,

- trasformace do S-JTSK,

- vektorizace vztažných bodů parcel.

Scannované mapy je nutné uložit ve formátu podporovaném mapovým serverem (většina běžných rastrových formátů).

Před transformací do S-JTSK je třeba vzít v úvahu srážku mapy, která může činit až několik procent. Každý mapový list mění svůj tvar rozdílně a návaznost jednotlivých mapových listů je základní požadavek při transformaci. Deformaci mapy lze popsat pomocí interpolačních ploch určených svým okrajem. Transformace do S-JTSK se provádí z místního souřadnicového systému. Existuje několik metod transformace; pro účely použití v ISMO lze použít projektivní transformaci. Podrobnější informaci o digitalizaci analogových map uvádí Čada (2003).

Vektorizace vztažných bodů parcel se provádí na základě transformovaného rastrového podkladu a definiční body parcel se ukládají přímo do PostGIS.

Při importu hybridní mapy je již podkladová vektorová a rastrová vrstva k dispozici. Je pouze nutné vektorová data importovat z původního vektorového formátu do databáze PostGIS (to lze zajistit standardními funkcemi). Rastry jsou udržovány v souborovém systému serveru ve formě, která umožňuje jejich zpřístupnění klientovi spolu s ostatními daty. 
Závěrečná fáze importu je pro analogovou i hybridní mapu stejná. Tvorbou cizích klíču je třeba zajistit vazbu mezi definičními body parcel a SPI.

\section{Závěr}

Cílem příspěvku bylo vytvořit metodiku pro implementaci prostorového rozhraní informačního systému obce. Příspěvek je součástí projektu tvorby informačního systému, který by mohl být využíván menšími obcemi.

Z hlediska návrhu architektury technologického řešení ISMO lze vybudování prostorového rozhraní označit za stěžejní pilî́r, protože pokud navrhovaná architektura umožní práci s geografickými daty, je dostatečně robustní a funkční i pro práci s libovolným typem atributových dat. Atributové rozhraní je často velmi variabilní a je závislé na způsobu vedení agend v konkrétní obci a v rámci př́spěvku není detailně rozebíráno.

Řešení postavené na open source softwarových technologiích bylo zvoleno ze dvou důvodů:

- jednotlivé technologie jsou k dispozici zdarma,

- pokud je vybrána vhodná kombinace technologií, je již v dnešní době k dispozici dostatečná dokumentace, a to i v českém jazyce.

Tyto dva fakty způsobují, že instalace jednotlivých technologií a správa výsledného řešení je relativně jednoduchá. Obec si ji může dělat sama a nebo (častější př́ípad) si najmout firmu, která za přijatelnou cenu řešení navrhne, implementuje a následně provádí kvalifikovanou údržbu systému (viz. popis rolí systému v podkapitole Struktura).

Klíčovou částí prostorového rozhraní je agenda informující obec o stavu nemovitého majetku na jejím území (data katastru nemovitostí), informace o ochranných pásmech (životní prostředí, památková péče, vodní zdroje, atp.), vize rozvoje obce (územní plán, geografická poloha obce). V př́íspěvku jsou navržené datové zdroje (interní a externí), ze kterých je možné informace získat. V podstatě jsou možné tři cesty práce s podkladovými daty v ISMO:

- Periodický import aktualizovaných dat - použito pro data katastru nemovitostí, pomocí modulu import VF ISKN, případně dalších standardních funkcí navrhovaného řešení.

- Využití některého z formátů internetové mapové služby (nejčastěji WMS či WFS) požadovaná data se připojí do klienta ISMO přes standardní protokol. Využito pro ostatní data z externích zdrojů.

- Import a následná správa dat přímo v ISMO - lze využít zejména pro postupný převod dat z existujících (převážně atributových) analogových i digitálních datových bází obce.

Autoři se domnívají, že navrhovaný způsob implementace ISMO je dobrou alternativou k již existujícím (většinou komerčním) řešením. Nezastírají ovšem, že zejména v některých fázích prrípravy dat (transformací), je třeba využít komerční technologie. Zároveň se ukazuje jako vhodná alternativa neomezování operačního systému pouze na nekomerční variantu (Linux), ale ponechat rozhodnutí o operačním systému (jak na serverovém tak klientském hardware) na konkrétních možnostech a schopnostech uživatelůadministrátorů. 


\section{Reference}

1. CENIA. Portál veřejné správy České republiky. Online $e^{10}$

2. ČÚZK a (Český úřad zeměměřičský a katastrální). Rastrová data katastrálních map. Online $^{11}$ [Cit. 2006-05-05].

3. ČÚZK b (Český úřad zeměměřičský a katastrální). Výstupy dat ISKN ve výměnných formátech. Online ${ }^{12}$ [Cit. 2006-05-03].

4. FASTIE, Will. Understanding Client/Server Computing. In PC Magazine: "Enterprize Computing". Page 229-230. 1999. Online ${ }^{13}$ [Cit. 2006-4-30].

5. NOVOTNÝ, Jiří, ČERBA, Otakar. Informační systém malé obce. Západočeská univerzita v Plzni 2005.

6. OGC 05-008. OpenGIS® Web Services Common Specification. Open Geospatial Consortium. Version: 1.0.0. 2005.

7. OGC 99-049. OpenGIS Simple Features Specification For SQL. Open GIS Consortium, Inc. 1999. Online ${ }^{14}$ [Cit. 2006-05-04].

8. PAGE-JONES, Meilir. VORÁČEK, Karel. Základy objektově orientovaného návrhu v UML. 1. vyd. Praha : 2001. ISBN 80-247-0210-X.

9. The PostgreSQL Global Development Group. PostgreSQL 8.0.7 Documentation. 2005. Online $^{15}$ [Cit. 2006-02-16].

10. SEI (Software Engineering Institute), Carnegie Mellon University. Client/Server Software Architectures: An Overview. 2005. Online ${ }^{16}$. [Cit. 2006-4-30].

11. SHERMAN, Gary E. Quantum GIS User Guide. 2005. Version 0.7. Online ${ }^{17}$ [Cit. 200605-09].

12. Ústav pro hospodářskou úpravu lesů (ÚHÚL). Mapový server ÚHÚL. Online ${ }^{18}$ [Cit. 2006-05-09].

13. Vivid Solutions, Inc. JUMP Unified Mapping Platform Data Sheet. 2003. Version 1.0. . [Cit. 2006-03-29].

14. Vojenský geografický a hydrometeorologický úr̆ad (VGHMÚř). Izgard. Online ${ }^{19}$ [Cit. 2006-05-09].

\footnotetext{
${ }^{10}$ http://geoportal.cenia.cz/mapmaker/cenia/portal/

${ }^{11}$ http : //www . cuzk . cz/Dokument . aspx?PRARESKOD=998\&MENUID=0\&AKCE=DOC : 10-RASTR_DATAKM

${ }^{12}$ http : //www . cuzk. cz/Dokument . aspx?PRARESKOD=998\&MENUID=0\&AKCE=DOC : 10-VYSTUPY_DAT_ISKN_VFORMATY

${ }^{13}$ http://www. officewizard.com/books/clientserver/ClientServerComputing.htm

${ }^{14}$ http://www .opengeospatial.org/docs/99-049.pdf

${ }^{15}$ http: //www.postgresql.org/docs/8.0/interactive/index.html

${ }^{16}$ http://www.sei.cmu.edu/str/descriptions/clientserver_body.html

${ }^{17}$ http://qgis.org/releases/userguide.pdf

${ }^{18}$ http: //212.158.143.149/index .php

${ }^{19}$ http://arwen.ceu.cz/website/startovani
} 
15. Vyhláška o poskytování údajů z katastru nemovitostí České republiky, č.162/2001. Online ${ }^{20}$ [Cit. 2006-05-01].

${ }^{20}$ http: //www $\cdot$ podnikame.cz/zakony01/index $\cdot$ php3?co=Z2001162 